\title{
Kitap Tanıtımı-II
}

\section{Hatice K. Arpaguş, Osmanl ve Geleneksel İslâm, Marmara Üniversitesi İlâhiyat Fakültesi Vakfı Yayınları, İstanbul 2014, 498 s.}

\section{F. Sümeyye KILAÇ*}

Bu eser, yazarın, Osmanlı Halkının Geleneksel İslâm Anlayışı ve Kaynakları adlı doktora çalışmasının bir devamı niteliğinde olup eserin yazılış amaçlarından biri "Osmanlı dinî tarihiyle ilgili araştırmaların yetersizliğ $i$, halk üzerinde yapılan çalışmaların azh $\breve{g} \imath$ ", "halkın dinî ihtiyaçlarına cevap veren kaynaklar konusundaki araştırmaların sınırlı ve kısıtl olması" gibi nedenler olmakla birlikte temel amaç, halkın dinî anlayışına yön veren kaynakların ve kaynaklarda mevcut olan malzemenin analiz ve değerlendirmesini yapmaktır.

Ayrıca eserde, Osmanlının kendinden önce var olan geleneği devraldığı, bu geleneği kendi yapısında eriterek yeni ve eklektik bir görünüm kazandığı saptanmaktadır. Yine Osmanl1nın bir gelenek olarak teşekkül etmesinin sonucu olarak günümüz gelenekselci anlayış ile Osmanlı geleneğinin örtüşüp örtüşmediği incelenmekte, söz konusu gelenekselci yaklaşımların farklı ve benzer taraflarına değinmek de amaçlanmaktadır.

İki ana bölümden oluşan kitabın ilk bölümünde, ilmihal yazıcılığı araştırılmış, tarihten günümüze kadarki süreçte ilmihalin gelişimi, Osmanl-Türk toplumunda bir yazım türü olarak ortaya çıkışı ve muhtevasının nasıl oluştuğu, incelenen hususlar içinde yer almıştır. İlmihalin hangi amaçla ve ne zaman ortaya çıktığı konusunda çok sınırlı çalışma bulunduğundan, kitabın bu kısmı, alanında en geniş ve ilk çalışma olma niteliğini taşımaktadır. Yine bu bölümde meselenin daha iyi anlaşılması için ekler kısmı oluşturulmuş, birinci ekte mevcut bazı ilmihal örnekleri, ikinci ekte de ilmihal yazımında nelere dikkat edilmesi gerektiğini konu edinen bir makale yer almıştır.

İlk Türkçe ilmihallerden olan Abdurrahman b. Yusuf Aksarâyînin İmâdü'l-İslâm adlı eseri ayrı bir bölüm olarak işlenmekte; eserin kaynakları, bu eserde kullanılan dil, üslup ve muhteva ayrıntılı olarak ele alınmaktadır. Bu ilmihallerin yazılış amacının halkın eğitim ve öğretim faaliyetlerine katkıda bulunmak gibi bir gayeyi gözettiği ve bu eserlerin dönemin anlayışına ayna tuttuğu belirtilmektedir. İmâdü'l-İslâm'la ilgili olarak ele alınan bu makale, alanında ilk çalışmadır. Burada İmâdu'l-İslâm’la birlikte tercüme hareketlerine yeni bir bakış açısı (genişletilmiş tercüme çalışmaları) kazandırıldığının saptanması dikkat çekici bir husus olarak karşımıza çıkmaktadır.

* MÜSBE Temel İslâm İlimleri Anabilim Dalı Kelâm Bilim Dalı Yüksek Lisans Öğrencisi 
Yine bu bölümde Osmanlı halkının peygamber tasavvurunun oluşmasında çok büyük bir paya sahip olan Yazıcıoğlu Mehmed ve onun Muhammediyye'siyle ilgili geniş bir malumat sunulmaktadır. Bu makale iki bölümde incelenmekte olup, ilk bölümde müellif Yazıcıoğlu Mehmed araştırılmış; ikinci ve asıl bölümde ise Muhammediyye'nin muhtevası, kaynakları, edebî özellikleri ve nüshaları hakkında ayrıntılı bilgiler nakledilmektedir. Bu eserle ilgili olarak, yazarın, Muhammediyye'nin edebî nitelikleri açısından yeni bir yazım türü olduğu tespiti oldukça önem arz etmektedir.

Osmanlı halkının dinî kimliğinin oluşumunda etkili bir başka eser, dua kitabı hüviyetindeki Delâilü'l-hayrât'ın oldukça yaygın şerhi Kara Dâvûd'tur. Söz konusu bu eserin müellifi tam olarak tespit edilememiştir. Ancak eserin müellifini Bursalı Mehmed Tahir, Kara Dâvûd İzmitî olarak kaydetmektedir. Araştırması sırasında yazar Arpaguş da buradan hareketle Kara Dâvûdzâdeler adı altında müderris bir ailenin var olduğunu ortaya koymuş ve bu şerhin müellifinin de bu aileden olabileceğini tespit etmiştir.

Eserin bu kısmında yazar, Osmanlı ilim anlayışının nasıl oluştuğunun cevaplarını aramaktadır. Aynı zamanda eserlerin şifahi eğitime uygun olduğu için sistematik olmadığı tespiti de ortaya konmaktadır. İlmihallerin ilk defa bu kadar geniş bir şekilde ele alınması da ilmihallerin bugün yeniden okunması gerektiğinin sinyallerini vermektedir.

Osmanlı halkının İslâm’ anlamasına ve yaşamasına katkı sağlayan bu eserlerin tanıtılması ve incelenmesinden sonra, ortaya konan tezi desteklemek, Osmanlı yaşayışından örnekler sunmak amacıyla, "Osmanlı Dinî Hayatından Görünümler" adlı bir başlık açılmış, bu başlıkta ibadet merkezli dinî yaşantının unsurlarından olan namaz, oruç, ramazan, ramazanda yapılan nafile ibadetler, bayramlar, kurban kesme, zekât-sadaka, hac gibi İslâm’ın temel rukûnlerinin Osmanlı hayatındaki yansımaları aktarılmıştır. Aynı zamanda eğitim merkezli faaliyetlerin unsurlarından olan huzur dersleri, otodidakt eğitim merkezleri tanıtılmış olup, burada okutulan eserler zikredilmiş, bu kurumların toplumun sosyal yaşamındaki etkileri ortaya konulmaya çalışılmıştır.

Eserin ikinci ana bölümünde yazar, halk İslâm’ı ve gelenek kavramı üzerinde durmuş, halkın beslendiği kaynakların en önemlilerinden olan ve aynı zamanda da geleneği şekillendiren şifahi kültürün tanımı ve kapsamından istifade etmeye çalışmıştır. Bu bölümün omurgasını oluşturan ise "gelenek" kavramıdır. Ancak ilk planda akla gelen ve Batı'da gelişen "Tradisyonel" hareketin gelenek tanımından hareket eden kitap, bunu Osmanlı geleneksel yapıs1na uyarlamaya çalışmaktadır. Nitekim burada geleneğin süreklilik, istikrar, hiyerarşi, otorite, kutsiyet ve ortodoksi gibi önemli özelliklerinden hareketle gelenek tanımına ulaşılmaya çalışmaktadır. Bu bağlamda Osmanlı halk İslâm’’ ele alınarak geleneksel ekolün bir sistem olarak ortaya koyduğu gelenek ve gelenekselciliğin, Osmanlı halk metinlerinin İslâm anlayışıyla paralellik arz edip etmediği mukayese edilerek farklı çerçevede geliştiği sonucuna varılmaktadır. Bu bölümde yazarın ulaştığı önemli sonuçlardan bir diğeri ise şifahî kültürden beslenen halk metinlerinin, zamanlarının gerektirdiği ölçüde görevlerini yerine getirmiş olsalar da metinlerde yer alan bilgilerin doğru olmaları bakımından başarısız oldukları tespitidir. Zira her ne kadar eserlerdeki bilgiler Kur'ân-1 Kerîm ve rivayetlerden istifade edilerek kaleme alınsa da bazı konuların kaynağı araştıııldığında bunların eski Türk menkıbe ve efsaneleri yanında Uzakdoğu kültürleri ile Ehl-i Kitab’n apokrif yorumlarına dayandığı görülmektedir. Diğer bir ifadeyle konuların anlatımında mitik malzemeden sık sık istifade edilme yoluna gidildiği ve 
bu konuların en belli başlıları arasında dünyanın yaratılışı ve sonu ile Hz. Peygamber'in peygamberlik ve beşer konumunun dışına çlkacak bir sürece girildiği görülmektedir. Bu tespite örnek olması amacıyla Osmanlı halkının peygamber algısı incelenmiş olup; Osmanlı halkının peygamber tasavvurunun mitolojiden beslenip mucize ile şekillendiği ortaya konulmaktadır. Bu tespite bir başka örnek ise kıssalardır. Tıpkı peygamber algısında olduğu gibi kıssalar da değerlendirildiğinde bunların İslâmî motiflerle farklı dinî veya kültürel unsurları mezcettikleri tespit edilmektedir. Yine eserde vurgulanan bir diğer nokta da halkın, din eğitiminde sıkça başvurduğu ve halk tarafından muteber kabul edilen tefsirlerde yer alan İslâmî şekle bürümüş kıssa ve mitik malzemenin hadis adı altında metinlerde yer almasıdır. Bu metinlerin, Kur'ân-1 Kerîm tefsirinde müracaat edilen bir kaynak olarak görülmesi bu eserlerdeki bilgilerin tefsir usûlü ve hadis tekniği açısından yeniden ele alınıp incelenmesi gerektiğini ortaya koymaktadır.

Eserin son bölümünde yazar, Osmanlı dönemi Muhyiddîn İbnü'l-Arabî şarihlerinden Sofyalı Bâli Efendi’nin Kazâ ve Kader Risalesìnin Arapça neşri ile Türkçe tercümesini yayımlamıştır. Daha sonra, Vahdet-i Vücud anlayışının şekillenişinde önemli yeri bulunan âyân-1 sâbite teorisini ve bu çerçevede Allah’in ilminin, kulun iradesi ve özgürlüğüne katkısı incelemeye alınmıştır. Yazar, söz konusu araştırma sırasında bu bakış açısının kaza ve kader konusuna farklı bir çözüm getirip getirmeyeceğini inceledikten sonra meseleyi çözüme kavuşturacak bir yaklaşım olmasa da bu bakış açısının pan-enteist anlayışın doğmasına zemin oluşturduğu tespitinde bulunmaktadır.

Oldukça hacimli bir eser olan Osmanl ve Geleneksel İslâm, müellifin önsözde de belirttiği üzere doktora sonrası yaptığ çalışmalardan oluştuğundan yer yer tekrarların olması ve yeterince sistematik olmaması yönüyle eleştirilebilir bir görünüm arz etmektedir. Ancak, oldukça sade bir üslup ile kaleme alınmış olması ve hem akademisyenler hem de halk için kaynak niteliğinde olması yönüyle eser başarılı bir çalışmadır. Aynı zamanda eserin, her ne kadar öncelikli hedefi ilâhiyat sahası çalışmaları gibi görünse de tarih, sosyoloji gibi farklı alanların akademik çalışmalarına da hitap ettiği vurgulanmalıdır. Eserde Osmanlı dinî ve sosyal tarihinin araştırılmış olması, Osmanlının çok yönlü bakış açısıyla incelenmeye müsait olduğunu ortaya koymaktadır. Ayrıca eser, bu alanlardaki nadir sayılabilecek çalışmalar arasında yer almaktadır. Bu durum, eserin kendi sahasında önemli bir boşluğu doldurmuş olduğunu ve yapılan ilk çalışmalardan biri olarak karşımıza çıktığını göstermektedir. 